\title{
Supervision and Law Enforcement on Intelligent Transportation Systems on the Highway
}

\author{
Nur Kumala dewi \\ Faculty of Information System, STMIK Muhammadiyah Jakarta, Indonesia \\ ${ }^{*}$ Corresponding author: \\ Email:nkd.mandori@gmail.com
}

\begin{abstract}
.
This research discusses the supervision and law enforcement on the transportation system, which will be applied to the smart transportation system. With this system, the police and local governments will be able to monitor the transportation system in a city, especially law enforcement on roads. The method used in this study is to use a literature review which is the basis for this research, by using a literature review it will be able to deepen a research, and be able to understand previous studies in order to create new research. The problem raised in this research is how to apply law enforcement on the highway to land transportation, both public vehicles and private vehicles that are on the highway every day, with strict law enforcement it will reduce crime on the road and can reduce accidents on the road Highway. This research will produce a proposed system, which can be used by the police and local governments in enforcing the law on public or private vehicles on the road.
\end{abstract}

Keyword: Law Enforcement, Smart Transportation, System, Highway.

\section{INTRODUCTION}

Law enforcement on the highway is still not optimal because it is still carried out manually by conducting motorized vehicle raids on the highway, raids are carried out in places that are considered by motorists to have committed many violations, this system is quite effective but can still be developed so that it can exceed At maximum, in carrying out legal action on the highway, there are motorized vehicles, both two-wheeled and four-wheeled or more, by making a system that can help the police in taking action, it will ease the work of the Police in taking action[1].

The system used for prosecution of motorized vehicle riders on the road is to place CCTV on the highway, to record violations that have been committed by motorized vehicle riders[2], which can be used as evidence for ticket penalties, with this CCTV system it can ticket motorists and provide notification notifications e-mailing of traffic rule violators on the highway[3].

The problem raised in this research is that by giving strict penalties to violators of regulations on the highway, the prosecution must be carried out without any voting songs[4], with a system so that all errors from violations of the law on the highway will be recorded by the system, and given appropriate penalties to offenders who have committed traffic offenses on the road[5].

The method used in this research is based on literature reviews from previously published journals, using journals will be able to make a strong research basis[6], and can make this research developed at a later date, because this research is the latest recent research[7].

This research will produce a proposed system that can be applied to law enforcement in the traffic sector[8], especially the application of intelligent transportation systems that already use artificial intelligence[9], which is a developmental problem of the existing transportation system in the smart city of Jakarta[10]. 


\section{METHOD}

This section describes how this research uses a method, for this research it does not go out of the way of the predetermined problems[11], as for the pictures and explanations can be seen below:

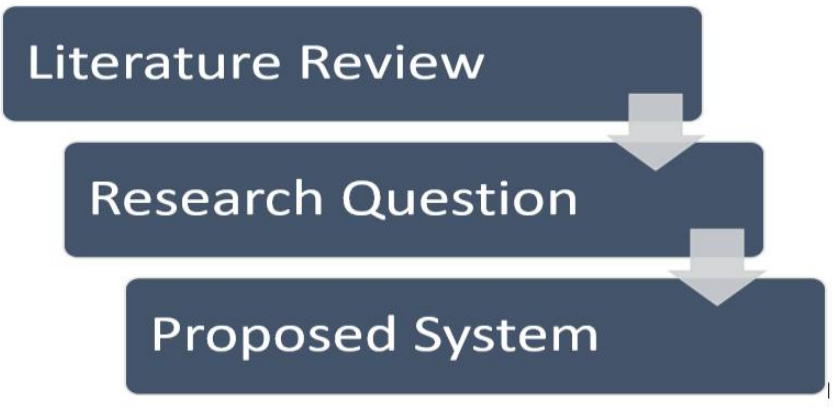

Figure 1. Research Method

\section{Literature Review}

In this study using the literature review method based on previous journals, because reading journals will broaden the researchers' insight and can also add to the research features of this research[12], with literature reviews, similar research can be combined and can be used as a benchmark for research in the future.

2. Research Question

Research question can be obtained after we read many journals by comparing previous research, to get new research problems, based on previous research can also be the basis for future research[13].

3. Proposed System

The final stage in this research is to make a system proposal, which can be used by the Police in enforcing the law on the highway, to motorists who have committed an offense[14], so that they can receive appropriate punishment, for example, such as a fine and a fine based on wrongdoing which has been done[15].

Based on the research method above, the next stage is to conduct research and discussion, the next stages can be seen below.

\section{RESULT AND DISCUSION}

This section will review data from previous journals[16], and make system proposals that will be able to solve the problems that have been determined at the beginning of this research, by conducting research it will be the basis of research and can be scientifically proven[17], as for the pictures and explanations that can be seen below this:

\section{Literature Review}

In the literature review section, it will explain the basics of research taken from previous research, with this research it can be concluded that the data we will process in this research[18], with the existence of previous journals whose research is the same in this research, it will be able to produce a suggestion[19]. the maximum system, as for the literature review on which this research is based can be seen in the table below:

Table 1. Literature Review

\begin{tabular}{|c|c|c|c|c|}
\hline No & Author & Year & Conclution & Journal \\
\hline 1 & Ahmed, Syed & 2015 & The use of the VANET application in the law & International \\
\hline
\end{tabular}




\begin{tabular}{|c|c|c|c|c|}
\hline & $\begin{array}{l}\text { Hassan } \\
\text { Yaqub, M. A. } \\
\text { Bouk, S. H. } \\
\text { Kim, Dongkyun }\end{array}$ & & $\begin{array}{l}\text { enforcement system on the highway will be } \\
\text { maximized, if it is carried out with strict } \\
\text { action given to motor vehicle offenders, using } \\
\text { the VANET application will greatly assist the } \\
\text { police in carrying out law enforcement on the } \\
\text { highway. }\end{array}$ & $\begin{array}{l}\text { Conference on } \\
\text { Ubiquitous and } \\
\text { Future } \\
\text { Networks, } \\
\text { ICUFN }\end{array}$ \\
\hline 2 & $\begin{array}{l}\text { Schwarting, } \\
\text { Wilko } \\
\text { Alonso-Mora, } \\
\text { Javier } \\
\text { Rus, Daniela }\end{array}$ & 2018 & $\begin{array}{l}\text { This journal describes an automatic vehicle } \\
\text { that can run by itself without a rider, with this } \\
\text { system it will be able to reduce the accident } \\
\text { rate and can make all motorized vehicles } \\
\text { become more orderly and and automatic } \\
\text { vehicles can also help the motorists who drive } \\
\text { them. }\end{array}$ & $\begin{array}{l}\text { Annual Review } \\
\text { of Control, } \\
\text { Robotics, and } \\
\text { Autonomous } \\
\text { Systems }\end{array}$ \\
\hline 3 & $\begin{array}{l}\text { Agbali, } \\
\text { Mohammed } \\
\text { Trillo, Claudia } \\
\text { Fernando, } \\
\text { Terrence } \\
\text { Ibrahim, Isa Ali } \\
\text { Arayici, Yusuf }\end{array}$ & 2019 & $\begin{array}{l}\text { With the concept of a smart city, everything } \\
\text { will be connected to a large system, with this } \\
\text { large system, all systems will be made, for } \\
\text { example the transportation system, building } \\
\text { system, hospital system and other systems. } \\
\text { Therefore, with the connected system, } \\
\text { transportation supervision will be much easier } \\
\text { and much more good again. }\end{array}$ & $\begin{array}{l}\text { Proceedings of } \\
\text { the 2nd World } \\
\text { Conference on } \\
\text { Smart Trends in } \\
\text { Systems, } \\
\text { Security and } \\
\text { Sustainability, } \\
\text { WorldS4 } 2018\end{array}$ \\
\hline 4 & $\begin{array}{l}\text { Appathurai, } \\
\text { Ahilan } \\
\text { Sundarasekar, } \\
\text { Revathi } \\
\text { Raja, C. } \\
\text { Alex, E. John } \\
\text { Palagan, C. Anna } \\
\text { Nithya, A. }\end{array}$ & 2020 & $\begin{array}{l}\text { Surveillance by using video so that it is } \\
\text { maximized at certain hours, because } \\
\text { congestion usually occurs at certain hours } \\
\text { such as time to go to work and time to come } \\
\text { home from work, therefore the use of video is } \\
\text { the right medium for monitoring and } \\
\text { enforcing traffic laws on the highway. }\end{array}$ & $\begin{array}{l}\text { Circuits, } \\
\text { Systems, and } \\
\text { Signal } \\
\text { Processing }\end{array}$ \\
\hline 5 & $\begin{array}{l}\text { Cardullo, Paolo } \\
\text { Kitchin, Rob }\end{array}$ & 2019 & $\begin{array}{l}\text { Part of a smart city is a smart community with } \\
\text { a smart community, all systems created by the } \\
\text { government will be maximized and can be } \\
\text { used by all smart people because basically } \\
\text { they already understand and understand the } \\
\text { existence of a system, which will be able to } \\
\text { help them in their daily lives. }\end{array}$ & GeoJournal \\
\hline 6 & $\begin{array}{l}\text { Zhang, Fukai } \\
\text { Li, Ce } \\
\text { Yang, Feng }\end{array}$ & 2019 & $\begin{array}{l}\text { Vehicle detection in this study uses video- } \\
\text { based, with video, vehicles can be detected } \\
\text { using the Deep learning classification method, } \\
\text { on vehicle data that passes through a road } \\
\text { taken on video, with the presence of vehicle } \\
\text { detectors and this can be seen the pattern of } \\
\text { violations and the patterns of vehicles that } \\
\text { commit an error on a certain road. }\end{array}$ & $\begin{array}{l}\text { Sensors } \\
\text { (Switzerland) }\end{array}$ \\
\hline
\end{tabular}

Based on the results of the literature review in the previous journal above, data can be obtained and the following conclusions can be obtained:

- Applications are the right media used to carry out surveillance and enforcement on motorized vehicles on the highway[1].

- The use of CCTV is the right medium for taking pictures or photos that can be used as a basis for decision making, which will result in a legal decision in the form of a ticket[20]. 
- Classification of vehicles according to violation patterns and vehicle patterns is one way of determining the pattern to be used in the supervision and enforcement of motorized vehicles on the highway[21].

Based on data obtained from the police, there are 15 types of violations commonly committed by motor vehicle offenders on the highway, the types of violations can be seen in table 2 below:

Table 2. 15 Offense on the Highway

\begin{tabular}{|c|l|}
\hline No & \multicolumn{1}{|c|}{15 Offense on the Highway } \\
\hline 1 & Use a cell phone while driving a motor vehicle. \\
\hline 2 & Driving a motorized vehicle on the sidewalk. \\
\hline 3 & Driving a motorized vehicle against the current. \\
\hline 4 & Driving a motorized vehicle across the busway (busway). \\
\hline 5 & Driving a motorized vehicle across the shoulder of the road. \\
\hline 6 & Motorbikes crossing or entering toll roads. \\
\hline 7 & Motorbikes cross non-toll elevated roads. \\
\hline 8 & $\begin{array}{l}\text { Driving a motorized vehicle violates government regulations or prohibitions that are stated } \\
\text { by means of traffic signals (APILL). }\end{array}$ \\
\hline 9 & Drivers who do not give priority to road users who have the main right to precedence. \\
\hline 10 & Driving a motorized vehicle over the speed limit. \\
\hline 11 & Driving a motorized vehicle does not use the Indonesian National Standard Helmet (SNI). \\
\hline 12 & Driving a motorized vehicle that allows passengers not to use an SNI helmet. \\
\hline 13 & Driving a motorized vehicle on the road without turning on the main lights at night. \\
\hline 14 & $\begin{array}{l}\text { Driving a motorized vehicle at a railroad crossing that does not stop when the signal sounds, } \\
\text { the railroad latches have started to close. }\end{array}$ \\
\hline 15 & Driving a motorized vehicle on the road. \\
\hline
\end{tabular}

Source : Head of sub-directorate for law enforcement, traffic directorate at Polda Metro Jaya

\section{Proposed System}

This section will discuss how the proposed system in this research, with the proposed system will complement the existing system and can also improve previous studies[22], so that this research becomes the latest research and can be the basis of research. In the future, the pictures and explanations can be seen below:

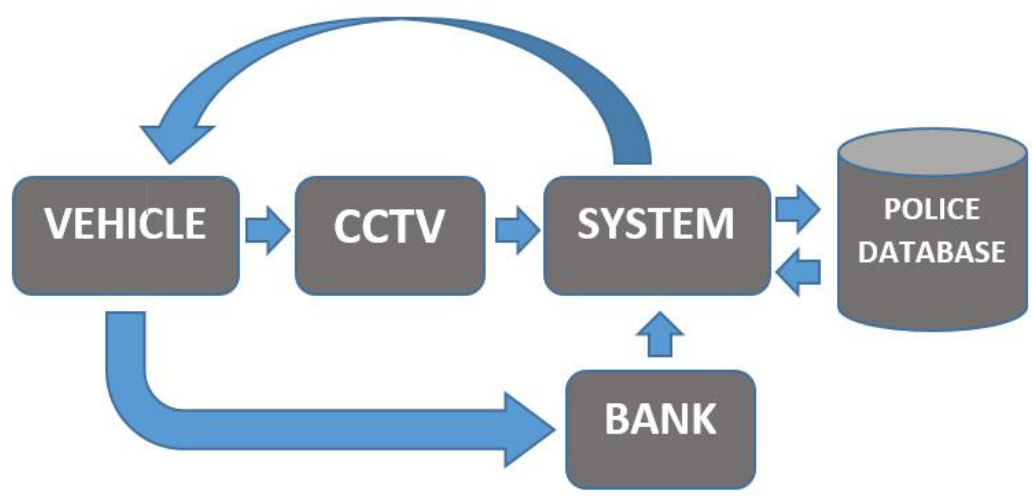

Figure 2. Proposed System

Based on the picture above, it will be explained in the explanation below:

- Vehicle 
The vehicles in this research are motorized vehicles that are used by motorists to drive on the highway, and commit violations on the highway, with a violation[21], motorized vehicles can be subject to a ticket sanction based on evidence obtained from CCTV.

- CCTV

CCTV is a tool used to record images that will be used as evidence of a motorized vehicle making a mistake, with the presence of the image[22], the prohibitor cannot argue that he has committed a violation, CCTV is a tool that is very suitable for use on the highway because it can withstand all weather conditions, and and can produce maximum images to be used as proof of a ticket.

- System

The system is a medium that is used to collect data from CCTV in the field, with this system media, the police will be able to monitor all the data sent by CCTV[23], and it can be processed to be used as evidence as a basis for prosecution for a ticket penalty, with the system then the work of the police will become easier in the field of supervision and enforcement.

- Police Data Base

The police database is a place to store all data that has been obtained from CCTV, and can be used as data for the basis for prosecution of motor vehicle offenders on the highway[24], the police database is a place to look for old and new data, because with a database, all large amounts of data can be used. stored as 1 , so that it can be used at a later date for compliance for prosecution purposes or data violations.

- Bank

The bank is the media used for the payment system in the proposed system this time, with the existence of a bank, all financial transactions related to objects of a ticket will be carried out automatically from the bank[25], with the banking system connected to the electronic system in this proposed system will make a list of paying offenses will be easier to monitor and record for future purposes.

\section{CONCLUTION}

The conclusion in this research is that with the use of CCTV and connected all systems to the police system, the supervision and action on motorized vehicles in traffic will be maximized, because the supporting data is based on literature review based on previous research, with the proposed system it can be done. complete previous studies so that it can become a perfect system, by using the system, all payment systems will be handled by the bank, so that the police do not take care of the payment of fines from tickets given to motor vehicle offenders on the highway, database In this study, it can form a very large data base and this data can be used to be able to make future patterns of violations and action patterns, and also the data can be stored as evidence for future law.

Future research is to make applications related to supervision and law enforcement on the highway, by making this application, the police will be greatly helped from all sides of surveillance of prosecution and punishment for motor vehicle violations on the highway.

\section{REFERENCE}

[1] S. H. Ahmed, M. A. Yaqub, S. H. Bouk, and D. Kim, "Towards content-centric traffic ticketing in VANETs: An application perspective," Int. Conf. Ubiquitous Futur. Networks, ICUFN, vol. 2015-Augus, pp. 237-239, 2015, doi: 10.1109/ICUFN.2015.7182541.

[2] W. Schwarting, J. Alonso-Mora, and D. Rus, "Planning and Decision-Making for Autonomous Vehicles," Annu. Rev. Control. Robot. Auton. Syst., vol. 1, no. 1, pp. 187-210, 2018, doi: 10.1146/annurev-control-060117-105157. 
[3] J. Chang, L. Wang, G. Meng, S. Xiang, and C. Pan, "Vision-based occlusion handling and vehicle classification for traffic surveillance systems," IEEE Intell. Transp. Syst. Mag., vol. 10, no. 2, pp. 80-92, 2018, doi: 10.1109/MITS.2018.2806619.

[4] M. Agbali, C. Trillo, T. Fernando, I. A. Ibrahim, and Y. Arayici, "Conceptual Smart City KPI Model: A System Dynamics Modelling Approach," Proc. 2nd World Conf. Smart Trends Syst. Secur. Sustain. WorldS4 2018, pp. 158-162, 2019, doi: 10.1109/WorldS4.2018.8611565.

[5] T. M. A.-U.-H. Bhuiyan, M. Das, and M. S. R. Sajib, "Computer vision based traffic monitoring and analyzing from on-road videos," Glob. J. Comput. Sci. Technol., vol. 19, no. 2, 2019.

[6] A. Appathurai, R. Sundarasekar, C. Raja, E. J. Alex, C. A. Palagan, and A. Nithya, "An Efficient Optimal Neural Network-Based Moving Vehicle Detection in Traffic Video Surveillance System," Circuits, Syst. Signal Process., vol. 39, no. 2, pp. 734-756, 2020, doi: 10.1007/s00034-019-012249.

[7] R. Cowley, S. Joss, and Y. Dayot, "The smart city and its publics: insights from across six UK cities," Urban Res. Pract., vol. 11, no. 1, pp. 53-77, 2018, doi: 10.1080/17535069.2017.1293150.

[8] P. Cardullo and R. Kitchin, "Being a 'citizen' in the smart city: up and down the scaffold of smart citizen participation in Dublin, Ireland," GeoJournal, vol. 84, no. 1, 2019, doi: 10.1007/s10708018-9845-8.

[9] P. Polack, F. Altche, B. DAndrea-Novel, and A. De La Fortelle, "The kinematic bicycle model: A consistent model for planning feasible trajectories for autonomous vehicles?," IEEE Intell. Veh. Symp. Proc., no. Iv, pp. 812-818, 2017, doi: 10.1109/IVS.2017.7995816.

[10] B. A. Alpatov, P. V. Babayan, and M. D. Ershov, "Vehicle detection and counting system for realtime traffic surveillance," 2018 7th Mediterr. Conf. Embed. Comput. MECO 2018 - Incl. ECYPS 2018, Proc., no. June, pp. 1-4, 2018, doi: 10.1109/MECO.2018.8406017.

[11] P. Wang, L. Li, Y. Jin, and G. Wang, "Detection of unwanted traffic congestion based on existing surveillance system using in freeway via a CNN-architecture trafficnet," Proc. 13th IEEE Conf. Ind. Electron. Appl. ICIEA 2018, no. 51505037, pp. 1134-1139, 2018, doi: 10.1109/ICIEA.2018.8397881.

[12] S. D. Pendleton et al., "Perception, planning, control, and coordination for autonomous vehicles," Machines, vol. 5, no. 1, pp. 1-54, 2017, doi: 10.3390/machines5010006.

[13] P. Wang et al., "Regional Detection of Traffic Congestion Using in a Large-Scale Surveillance System via Deep Residual TrafficNet," IEEE Access, vol. 6, pp. 68910-68919, 2018, doi: 10.1109/ACCESS.2018.2879809.

[14] N. K. Jain, R. K. Saini, and P. Mittal, A review on traffic monitoring system techniques, vol. 742. Springer Singapore, 2019.

[15] K. Nellore and G. P. Hancke, "A survey on urban traffic management system using wireless sensor networks," Sensors (Switzerland), vol. 16, no. 2, 2016, doi: 10.3390/s16020157.

[16] K. K. Santhosh, D. P. Dogra, and P. P. Roy, "Temporal Unknown Incremental Clustering Model for Analysis of Traffic Surveillance Videos," IEEE Trans. Intell. Transp. Syst., vol. 20, no. 5, pp. 1762-1773, 2019, doi: 10.1109/TITS.2018.2834958.

[17] V. Vahidi, E. Saberinia, and B. T. Morris, "OFDM Performance assessment for traffic surveillance in drone small cells," IEEE Trans. Intell. Transp. Syst., vol. 20, no. 8, pp. 2869-2878, 2019, doi: 10.1109/TITS.2018.2868761.

[18] T. Durand, X. He, I. Pop, and L. Robinault, Utilizing deep object detector for video surveillance indexing and retrieval, vol. 11296 LNCS. Springer International Publishing, 2019.

[19] Z. Al-Ars, S. van der Vlugt, P. Jääskeläinen, and F. van der Linden, "ALMARVI System Solution 
for Image and Video Processing in Healthcare, Surveillance and Mobile Applications," J. Signal Process. Syst., vol. 91, no. 1, pp. 1-7, 2019, doi: 10.1007/s11265-018-1423-2.

[20] M. Angelidou, A. Psaltoglou, N. Komninos, C. Kakderi, P. Tsarchopoulos, and A. Panori, "Enhancing sustainable urban development through smart city applications," J. Sci. Technol. Policy Manag., vol. 9, no. 2, pp. 146-169, 2018, doi: 10.1108/JSTPM-05-2017-0016.

[21] J. Sochor, J. Spanhel, and A. Herout, "BoxCars: Improving Fine-Grained Recognition of Vehicles Using 3-D Bounding Boxes in Traffic Surveillance," IEEE Trans. Intell. Transp. Syst., vol. 20, no. 1, pp. 97-108, 2019, doi: 10.1109/TITS.2018.2799228.

[22] J. Y. Wei, J. F. Zhao, Y. Y. Zhao, and Z. C. Zhao, "Unsupervised anomaly detection for traffic surveillance based on background modeling," IEEE Comput. Soc. Conf. Comput. Vis. Pattern Recognit. Work., vol. 2018-June, pp. 129-136, 2018, doi: 10.1109/CVPRW.2018.00025.

[23] M. Desai and A. Phadke, "Internet of Things based vehicle monitoring system," IFIP Int. Conf. Wirel. Opt. Commun. Networks, WOCN, pp. 1-3, 2017, doi: 10.1109/WOCN.2017.8065840.

[24] S. Parekh, N. Dhami, S. Patel, and J. Undavia, "Traffic signal automation through iot by sensing and detecting traffic intensity through ir sensors," Smart Innov. Syst. Technol., vol. 106, pp. 53-65, 2019, doi: 10.1007/978-981-13-1742-2_6.

[25] L. Wang et al., "Road traffic mortality in China: analysis of national surveillance data from 2006 to 2016," Lancet Public Heal., vol. 4, no. 5, pp. e245-e255, 2019, doi: 10.1016/S24682667(19)30057-X. 